\title{
Natural patches in Posidonia oceanica meadows: the seasonal biogeochemical pore water characteristics of two edge types
}

\author{
Arnaud Abadie $^{1,2}$ (1) $\cdot$ Alberto V. Borges ${ }^{3} \cdot$ Willy Champenois $^{3} \cdot$ Sylvie Gobert $^{2}$
}

Received: 7 December 2016 / Accepted: 11 July 2017

(c) Springer-Verlag GmbH Germany 2017

\begin{abstract}
Seagrass meadows can be assimilated to seascape matrixes encompassing a mosaic of natural and anthropogenic patches. Natural patches within the Mediterranean Posidonia oceanica meadows show a structural particularity which consist in a duality of their edge types. One edge is eroded by bottom currents, while the adjacent meadow colonizes the bare sediments. This study aims to study the dynamics of these two edges through the investigation of the biogeochemistry $(\mathrm{pH}$, total alkalinity, dissolved inorganic carbon, $\mathrm{CO}_{2}, \mathrm{CH}_{4}, \mathrm{~N}_{2} \mathrm{O}, \mathrm{H}_{2} \mathrm{~S}$, dissolved inorganic nitrogen, $\mathrm{PO}_{4}{ }^{3-}$ ) within vegetated and unvegetated sediments. These observations are compared with the adjacent meadow to have a better understanding of the colonization processes. Our results reveal that the $P$. oceanica matrix shows differences from the vegetated edges of sand patches, especially with regard to nutrient availability, which is generally more important at the colonized edge (dissolved inorganic nitrogen up to $65.39 \mu \mathrm{M}$ in June). A clear disparity also occurs between the eroded and colonized edge with both a seasonal and bathymetrical variation of leaf biomass with higher disparities at $10 \mathrm{~m}$ in June (colonized edge $1415 \mathrm{gDW} \mathrm{m}^{-2}$; eroded edge $1133 \mathrm{gDW} \mathrm{m}^{-2}$ ). The
\end{abstract}

Responsible Editor: M. Huettel.

Reviewed by S. Enriquez Dominguez and an undisclosed expert.

Arnaud Abadie

arnaudabadie@aol.fr

1 Station de Recherches Sous-marines et Oceanographiques (STARESO), Haute-Corse, France

2 Laboratory of Oceanology, MARE Centre, University of Liège, B6C, 4000 Liège, Belgium

3 Chemical Oceanography Unit, University of Liège, B5A, 4000 Liège, Belgium most important contrasts during this study were assessed in June, suggesting that the warm period of the year is more suitable for sampling to highlight disparate characteristics in temperate seagrass meadows. These findings put into light the potential importance of biogeochemical processes in the dynamics of natural patch edges. We hypothesize that they may influence the structural dynamics of $P$. oceanica seascapes.

\section{Introduction}

Among marine ecosystems, seagrass meadows are described (den Hartog 1970) and recognized as playing a dominant role by acting as a carbon sink (Fourqurean et al. 2012), creating a nursery for many commercial species (Beck et al. 2001) and sheltering coasts against erosion (Ondiviela et al. 2014). Over the last three decades, a new kind of approach, deriving from the terrestrial field, has emerged to investigate the functioning and evolution of seagrass ecosystems: the "seascape ecology" also called "marine space ecology" (Robbins and Bell 1994; Li and Mander 2009). The basis of this scientific discipline consists in studying the structure of the seascape, linking it with its function, i.e. its influence on the distribution of other organisms (Turner 1989). The structure of a seascape can be defined as the varying arrangements of biotic structures, with the resulting mosaic of marine habitat patches encompassed within a matrix (Robbins and Bell 1994).

The extensive meadows formed by the Mediterranean seagrass Posidonia oceanica (L.) Delile are particularly suitable for seascape studies due to the capacity of the plant to build complex structures. They provide a highly heterogeneous habitat, sheltering many important functional species, such as the sea urchin Paracentrotus lividus and 
the salema Sarpa salpa (Borg et al. 2006; Prado et al. 2009; Gera et al. 2013). In this way, a $P$. oceanica seascape corresponds to a set of different habitats, i.e. types of patch, of natural and anthropogenic origin included in a meadow matrix (Abadie et al. 2015). Natural patch types encompass a distinctive structure called "intermatte" or "sand corridor" (Fig. 1) generated by bottom currents stemming from wave energy, its boundaries being referred to as "edges" (Molinier and Picard 1952; Vacchi et al. 2017). Edges (or ecotones) in seascapes, and in a wider viewpoint in landscapes, are considered as interface location of two types of habitats (Forman 1995; Boström et al. 2006). They play an important functional role, with their structural characteristics conditioning organisms' distribution (Angelstam 1992).

When observing $P$. oceanica meadows surrounding sand corridors, two edges with contrasted dynamics are clearly observed (Fig. 1). On the one hand, a side is eroded by bottom currents forming a vertical edge (sediments, rhizomes and roots), and on the other hand the meadow recolonizes the bare sandy bottom with plagiotropic (horizontal) rhizomes (Gobert et al. 2016). Current speeds up to 12 and $8 \mathrm{~cm} \mathrm{~s}^{-1}$ were, respectively, observed at 15 and $20 \mathrm{~m}$ depth on this kind of patch (Gobert et al. 2016) far under $40 \mathrm{~cm} \mathrm{~s}^{-1}$, the speed at which $P$. oceanica survival is compromised in shallow areas (Infantes et al. 2009).

Our working hypothesis is that from this apparent structural duality between the two edges, a contrast of the sediment biogeochemistry should ensue. Indeed, $P$. oceanica is an autogenic ecosystemic engineer (Lawton 1994) able to modify the substrate through the release and uptake of chemical compounds (Marbà et al. 2006).

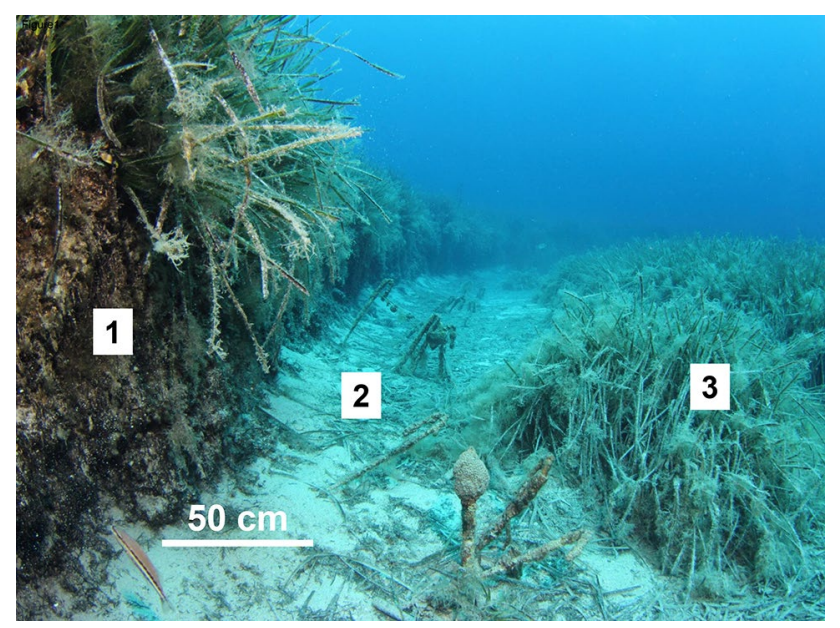

Fig. 1 Underwater photograph of a sand corridor within a Posidonia oceanica meadow in Calvi Bay $\left(42^{\circ} 34.823^{\prime} \mathrm{N} 8^{\circ} 43.433^{\prime} \mathrm{E}\right.$, Corsica, France) at $15 \mathrm{~m}$ depth. 1 Eroded vertical edge; 2 sandy bottom; 3 colonized edge (photo: A. Abadie)
In this way, $P$. oceanica meadows influence the carbonate balance by dissolving or producing $\mathrm{CaCO}_{3}$, thus modifying the uptake or release of $\mathrm{CO}_{2}$ (Barrón et al. 2006). $\mathrm{CaCO}_{3}$ dissolution in $P$. oceanica meadows could be driven by $\mathrm{H}_{2} \mathrm{~S}$ oxidation with $\mathrm{O}_{2}$ (Barrón et al. 2006) related to sulphate reduction that occurs within the anoxic layer of the sediment (Holmer et al. 2003, 2004) and diffusion of $\mathrm{O}_{2}$ or the hypothetical release of $\mathrm{O}_{2}$ by the roots (Ku et al. 1999; Burdige and Zimmerman 2002). Production of $\mathrm{CaCO}_{3}$ relates to calcification by epiphyte flora and fauna, as well as dwelling invertebrates (Canals and Ballesteros 1997). Although these processes have been studied within continuous $P$. oceanica beds and compared with unvegetated sediments (Holmer et al. 2003; Barrón et al. 2006; Holmer and Frederiksen 2007), no investigation considering their edge particularities exists to date.

Moreover, natural sandy patches are found all along the extent of P. oceanica meadows, i.e. from their deeper limit (down to $40 \mathrm{~m}$ depth) to depths closer to the shallower limit (10 m) (Clabaut et al. 2014). The same duality between eroded vertical edge and recolonization process occurs at all depths; however, patches display different sizes and shapes (Abadie et al. 2015). This structural difference of the seascape is expected to derive from chemical processes (associated with the plant dynamics) linked with light availability and water temperature (Elkalay et al. 2003; Díaz-Almela et al. 2009; Pedersen et al. 2011). Furthermore, $P$. oceanica seascape morphology is influenced by water movement even at the level of the deeper limit, although their speed, and thus influence, decreases with the depth (Vacchi et al. 2012, 2017).

Based on the structural disparities observed on natural sandy patches, we aimed to study the potential contrast of chemical processes that occur at the edge of seagrass meadows at different depths (10,15 and $20 \mathrm{~m})$. More specifically, we aim to answer four questions:

1. Is there a distinct sediment biogeochemical signature between a continuous $P$. oceanica meadow (the matrix) and its edges surrounding natural sandy patches?

2. Do the two types of edges differ in term of sediment biogeochemistry and plant biomass (eroded vertical edge versus colonized edge)?

3. Is there a seasonality in differences in (1) and (2)?

4. Do chemical processes in sediments differ with depth, and by extension the patch type?

Based on these four questions, this work intends to link the potential influence of $P$. oceanica on the sediments biogeochemistry dynamics with the structural characteristics of the seascape. 


\section{Materials and methods}

\section{Study site and in situ sampling}

The study took place in Calvi Bay (Corsica, France) near the STARESO research station along the Punta Revellata $\left(42^{\circ} 34.823^{\prime} \mathrm{N} 8^{\circ} 43.433^{\prime} \mathrm{E}\right.$; Fig. 2a). Six sites in three areas at 10,15 and $20 \mathrm{~m}$ depth encompassing a natural sandy patch $(\mathrm{P} 10,15,20)$ and a continuous meadow $(\mathrm{C} 10,15$, 20) were considered (Fig. 2b). At each site, the sediment pore water was sampled by scuba diving during the year 2015 in February, June and October. The sampling was carried out at 5 and $10 \mathrm{~cm}$ using $60 \mathrm{ml}$ syringes according to the method of Gobert et al. (2006). On sandy patches, sampling was carried out at both eroded and colonized edges, with a special focus on the closest collection to the meadow/bare sediment interface (Fig. 2c). In this way, the collection was performed in a range of $10 \mathrm{~cm}$ on either side of the colonization and the erosion (Fig. 2c). Water samples were directly stored or treated according to the chemical analyses required. Seawater temperature was measured during the sampling in February, and then every 10 min from April to December 2015 (Onset $^{\circledR}$
$\mathrm{HOBO}^{\circledR}$ Data Loggers UA-002-64 placed at 10, 15 and $20 \mathrm{~m}$ depth).

\section{Chemical analyses}

Sediment pore water chemistry was investigated through measurements of $\mathrm{pH}$, total alkalinity (TA), carbon dioxide partial pressure $\left(\mathrm{CCO}_{2}\right)$, hydrogen sulphur $\left(\mathrm{H}_{2} \mathrm{~S}\right)$, oxygen $\left(\mathrm{O}_{2}\right)$, methane $\left(\mathrm{CH}_{4}\right)$, nitrous oxide $\left(\mathrm{N}_{2} \mathrm{O}\right)$ and inorganic nutrients $\left(\mathrm{NO}_{2}^{-}, \mathrm{NO}_{3}{ }^{-}, \mathrm{NH}_{4}{ }^{+}\right.$and $\left.\mathrm{PO}_{4}{ }^{3-}\right)$. After sampling, syringes were stored in shadow and kept in an icebox at a low temperature for $\mathrm{O}_{2}$ and $\mathrm{H}_{2} \mathrm{~S}$ assessment. $30 \mathrm{ml}$ of their content was placed in serum bottles with $50 \mu \mathrm{l}$ of mercury chloride $\left(\mathrm{HgCl}_{2}\right)$ to stop biochemical processes for later $p \mathrm{CO}_{2}, \mathrm{Ch}_{4}$ and $\mathrm{N}_{2} \mathrm{O}$ analyses and hermetically crimped with butyl stoppers and aluminium caps.

At the laboratory, $\mathrm{pH}$ was immediately measured using a Metrohm ${ }^{\mathrm{TM}}$ 6.0202.100 electrode connected to a Metrohm ${ }^{\mathrm{TM}} 713 \mathrm{pH}$ Meter and temperature probe Metrohm ${ }^{\mathrm{TM}} \mathrm{Pt} 100$. The $\mathrm{pH}$ electrode was calibrated on the total hydrogen ion concentration scale, using 2amino-2-hydroxymethyl-1,3-propanediol (TRIS) and 2amino-pyridine (AMP) buffers prepared at a salinity of

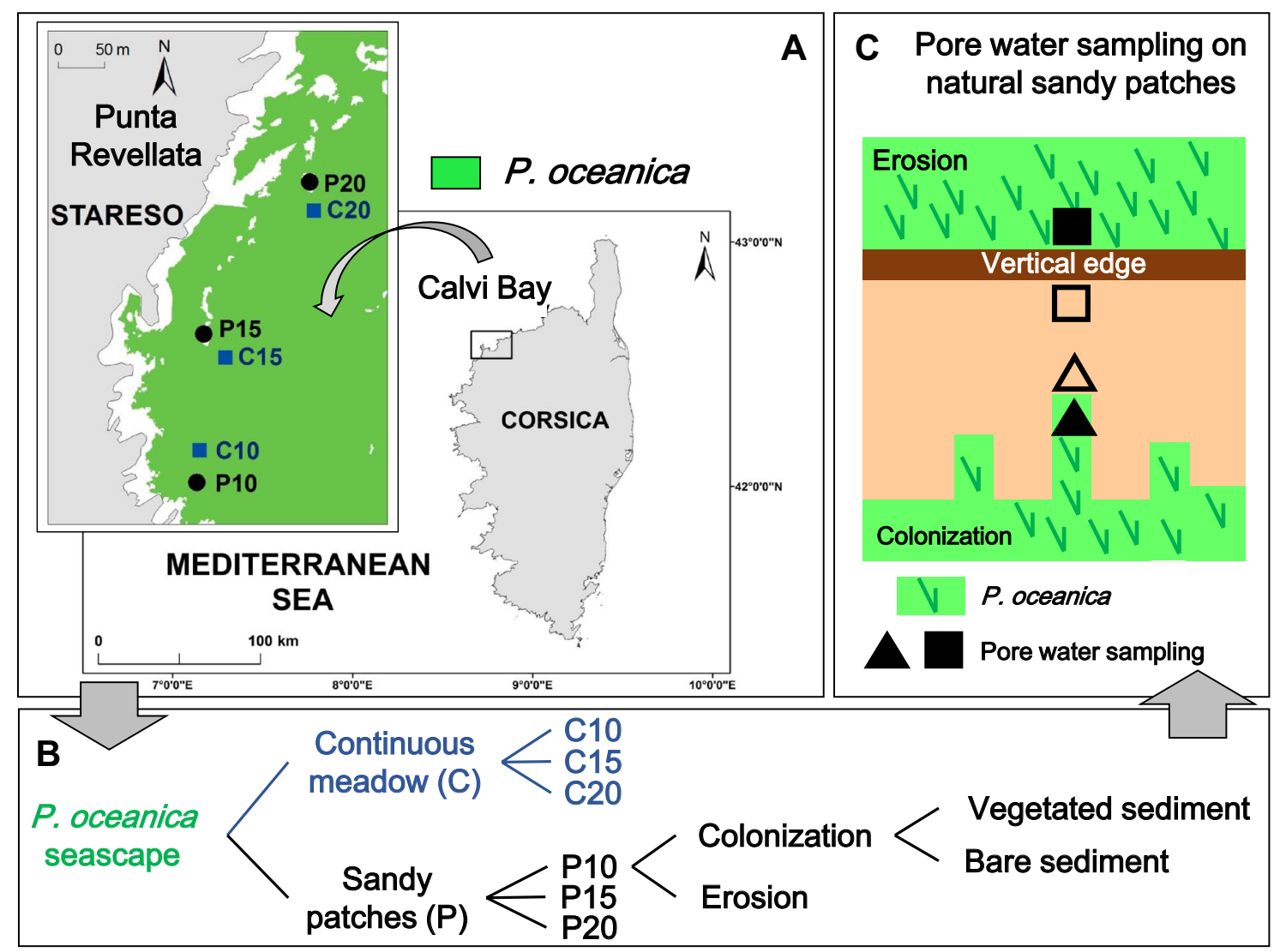

Fig. $2 a$ Map of the study site in Calvi Bay at Punta Revellata (Corsica, France); $b$ sampling strategy; $c$ vertical schematic representation of the pore water sampling on natural sandy patches. $P X$ sandy patch at depth $X, C X$ continuous meadow at depth $X$ 
38 (Dickson 1993). pH was re-calculated at in situ temperature with TA data and seawater temperature using the CO2sys software developed by Lewis and Wallace (1998). TA (Eq. 1) was measured with the open-cell titration technique, i.e. $\mathrm{HCl} 0.1 \mathrm{M}$ on $100 \mathrm{ml}$ filtered (PES syringe filter $0.2 \mu \mathrm{m}$ ) seawater samples (Gran 1952). DIC (Eq. 2) was computed from $p \mathrm{CO}_{2}$ (see hereafter) and TA with $\mathrm{CO} 2$ sys using the carbonic acid dissociation constants of Mehrbach et al. (1973) refitted by Dickson and Millero (1987).

$$
\begin{aligned}
\mathrm{TA}= & {\left[\mathrm{HCO}_{3}^{-}\right]+2[]+\left[\mathrm{B}(\mathrm{OH})_{4}^{-}\right]+[\text {minor ions }] } \\
& +\left[\mathrm{OH}^{-}\right]-\left[\mathrm{H}^{+}\right] \\
\mathrm{DIC}= & {\left[\mathrm{CO}_{2}\right]+\left[\mathrm{HCO}_{3}^{-}\right]+\left[\mathrm{CO}_{3}^{2-}\right], }
\end{aligned}
$$

$\mathrm{O}_{2}$ presence/absence was checked using an iodine titration with thiosulphate according to the Winkler method with an automatized system for small sampling volumes (Carpenter 1965; Strickland and Parsons 1972) adapted by R. Biondo (Laboratory of Oceanology-University of Liège). The $\mathrm{H}_{2} \mathrm{~S}$ concentration was measured with a silver/sulphide ISM-146 FTH 25-XS electrode, coupled with a sulphide anti-oxidant buffer (SAOB) solution given the protocol of Abadie et al. (2016) adapted from Brooks (2001).

$p \mathrm{CO}_{2}, \mathrm{CH}_{4}$, and $\mathrm{N}_{2} \mathrm{O}$ concentrations were measured by headspace equilibration method and gas chromatography (GC) (Weiss 1981) based on protocols described by Borges et al. (2015), using a flame ionization detector with a methanizer and electron capture detector (SRI $8610 \mathrm{C}$ ) calibrated with mixtures of $\mathrm{CH}_{4}: \mathrm{CO}_{2}: \mathrm{N}_{2} \mathrm{O}: \mathrm{N}_{2}$ (Air Liquide Belgium) of 404, 1018 and $3961 \mathrm{ppm} \mathrm{CO}_{2}, 1,10$ and $30 \mathrm{ppm} \mathrm{CH}_{4}$ and 0.2, 2.0 and $6.0 \mathrm{ppm} \mathrm{N}_{2} \mathrm{O}$.

Phosphate $\left(\mathrm{PO}_{4}{ }^{3-}\right)$, ammonium $\left(\mathrm{NH}_{4}{ }^{+}\right)$and nitrite $\left(\mathrm{NO}_{2}{ }^{-}\right)$/nitrate $\left(\mathrm{NO}_{3}{ }^{-}\right)$concentrations were measured using a SKALAR auto-analyzer following the method of Aminot and Kérouel (2007) adapted for oligotrophic samples (Laboratory of Oceanology-University of Liège).

\section{Leaf biomass assessment}

Meadow density was measured at each station by scuba diving with a $25 \mathrm{~cm} \times 40 \mathrm{~cm}$ quadrat $(n=10)$. In parallel, leaves were sampled $(n=20)$ for biometry and biomass assessment according to the nondestructive method (de los Santos et al. 2016). In laboratory, leaf biometry was performed (Giraud 1979) and epiphytes were stripped from the leaves with a razor blade (Dauby and Poulicek 1995). Leaves were dried in an oven at $60{ }^{\circ} \mathrm{C}$ during 4 days and then weighed.

\section{Statistical analysis}

Statistical analyses were performed under the R 3.0.2 software using the FactoMineR package. The normality of leaf biomass values was checked using a Shapiro-Wilk test. Stations were then statically tested two by two (continuous versus colonization versus erosion) for each depth (10, 15 and $20 \mathrm{~m}$ ) with one-way ANOVA (after checking their homoscedasticity with a Fisher test) for Gaussian data, and with a Kruskal-Wallis test for non-parametric ones. Oneway ANOVAs were followed by a Tukey post hoc test and Kruskal-Wallis tests by a Dunn's test.

At each depth, a principal component analysis (PCA) was performed by computing $\mathrm{pH}$, TA, DIC, $p \mathrm{CO}_{2}$, leaf biomass as well as concentrations of $\mathrm{CH}_{4}, \mathrm{~N}_{2} \mathrm{O}, \mathrm{H}_{2} \mathrm{~S}, \mathrm{NO}_{2}{ }^{-}, \mathrm{NO}_{3}{ }^{-}$, $\mathrm{NH}_{4}{ }^{+}$and $\mathrm{PO}_{4}{ }^{3-}$. The analysis was performed using a covariance matrix. Stations (individuals) were separated per the sampling month.

\section{Results}

\section{Physico-chemical features of natural sand corridors}

The seawater temperature ranged from $13.9{ }^{\circ} \mathrm{C}$ in April at $20 \mathrm{~m}$ to $28.1{ }^{\circ} \mathrm{C}$ in July at $10 \mathrm{~m}$ depth. The temperature showed clear seasonal variations (Fig. 3a) and thermal stratification occurred between May and October as shown by differences in temperature between 10 and $20 \mathrm{~m}$. Considering the illuminance, a greater decrease was observed between $10 \mathrm{~m}$ and 15/20 $\mathrm{m}$ depth with a higher contrast in spring and summer (Fig. 3b).

Considering the theoretical evolution to attain the highest TA and DIC values per the biogeochemical processes that can control these variables, aerobic respiration (aerobic resp.), sulphate reduction $\left(\mathrm{SO}_{4}\right.$ red.) and calcium carbonate dissolution $\left(\mathrm{CaCO}_{3}\right.$ dissol.), TA and DIC seemed to be mainly driven by the process of sulphate reduction in February, June and October at all stations and at 15 at $20 \mathrm{~m}$ depth (Fig. 4b, c). At $10 \mathrm{~m}$ depth (Fig. 4a), this observation differed at the level of the colonized edge where in June and October aerobic respiration and $\mathrm{CaCO}_{3}$ dissolution had also an influence on TA and DIC concentrations.

$\mathrm{H}_{2} \mathrm{~S}$ concentrations were the lowest in February (Fig. 4d-f). In June, high concentrations were found within the continuous meadow at 10 and $20 \mathrm{~m}$ depth (respectively, 10.3 and $10.0 \mu \mathrm{M}$ ), as well as at the colonized edge at $20 \mathrm{~m}$ depth, both inside the bare sediments and within the meadow (respectively 28.8 and $68.8 \mu \mathrm{M}$ ). In October, the highest concentrations were found within the continuous meadow (Fig. 4d, e) at 10 and $15 \mathrm{~m}$ depth (respectively 43.8 and $27.0 \mu \mathrm{M}$ ). 
Fig. 3 a Seawater temperature and; $\mathbf{b}$ light intensity at 10 (black), 15 (red) and $20 \mathrm{~m}$ (green) at sampling sites from April to December 2015. Black arrows indicate the in situ sampling date
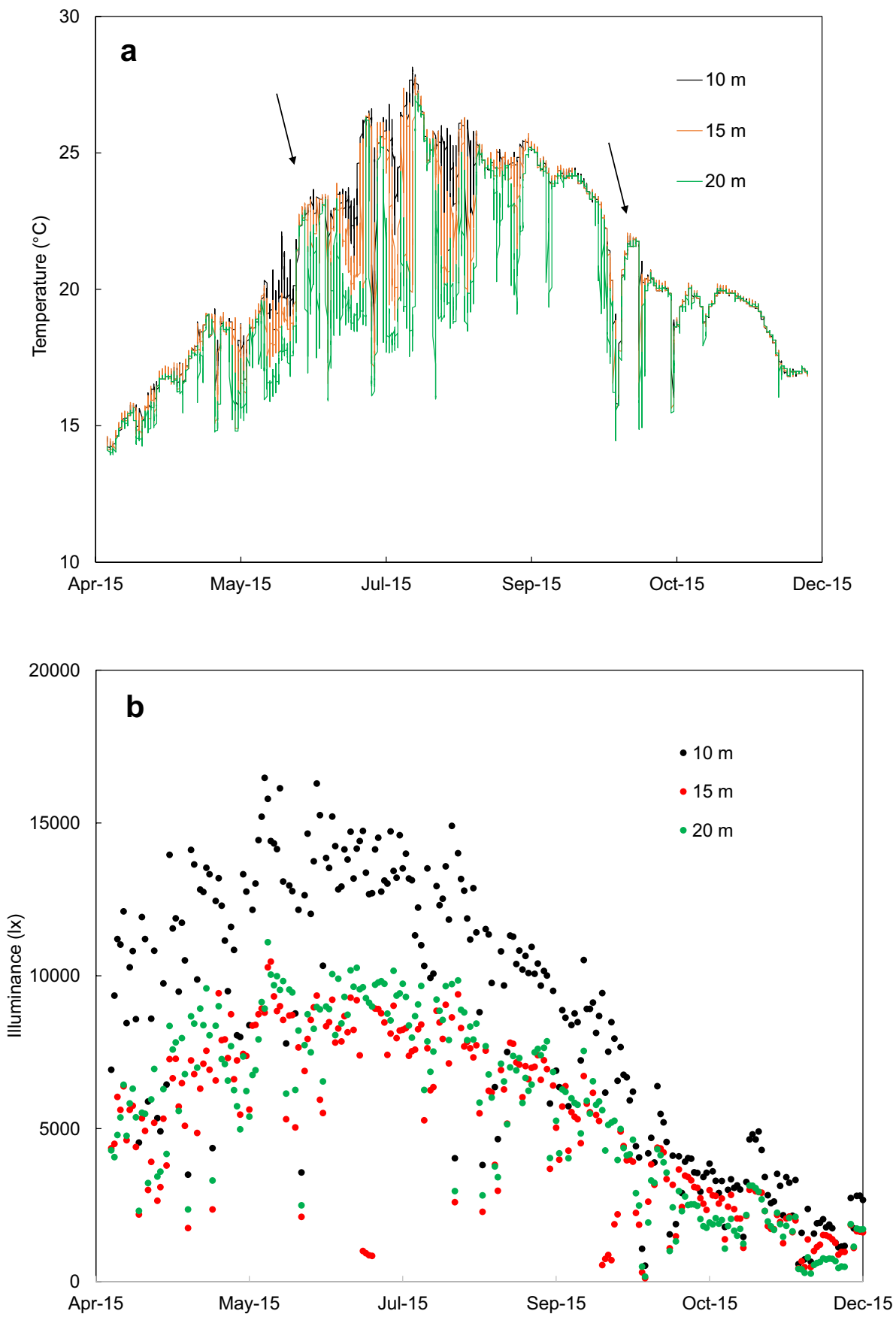

The values of $p \mathrm{CO}_{2}$ were low (around $2000 \mathrm{ppm}$ ) all along the 3 months sampled (Fig. 5). A different pattern was observed at the vegetated eroded edge and at the vegetated colonized one. Within the vegetated eroded edge, $p \mathrm{CO}_{2}$ increased in June (3.852 ppm) and remained high in October (3.369 ppm) at $10 \mathrm{~m}$ depth (Fig. 5). On the vegetated colonized edge, $p \mathrm{CO}_{2}$ increased in June at 10 and $15 \mathrm{~m}$ depth (respectively, 4.093 and $4.462 \mathrm{ppm}$ ) and then decreased in October. A reverse pattern was observed at this edge at $20 \mathrm{~m}$ (Fig. 5) with the highest value in October
(4.030 ppm). $\mathrm{CH}_{4}$ concentrations were low (under $500 \mathrm{nM}$, Fig. 5), except at $10 \mathrm{~m}$ depth at the vegetated colonized edge $(691 \mathrm{nM})$ as well as at $20 \mathrm{~m}$ at the colonized and eroded unvegetated edge (respectively, 1.487 and $506 \mathrm{nM}$ ). $\mathrm{N}_{2} \mathrm{O}$ values were found to be low at each depth and all sampling stations (Fig. 5), and unlike $\mathrm{CO}_{2}$ and $\mathrm{CH}_{4}$, the $\mathrm{N}_{2} \mathrm{O}$ values were below saturation (maximum $8.88 \mathrm{nM}$ in February).

Concentrations of inorganic nutrients increased with depth, generally with higher values in June (Table 1). 
Fig. 4 Total alkalinity (TA) as function of the dissolved inorganic carbon (DIC) and the hydrogen sulphur $\left(\mathrm{H}_{2} \mathrm{~S}\right)$ at 10, 15 and $20 \mathrm{~m}$ depth. Dotted lines indicate the theoretical evolution to attain the highest TA and DIC values according to the biogeochemical processes that can control these variables: aerobic respiration (aerobic resp.), sulphate reduction $\left(\mathrm{SO}_{4}\right.$ red.) and calcium carbonate dissolution $\left(\mathrm{CaCO}_{3}\right.$ dissol.). Vertical and horizontal bars indicate SD. Blue February; orange June; grey October. Circle continuous meadow; triangle colonization vegetated; empty triangle colonization bare sediments; square erosion vegetated; empty square erosion unvegetated
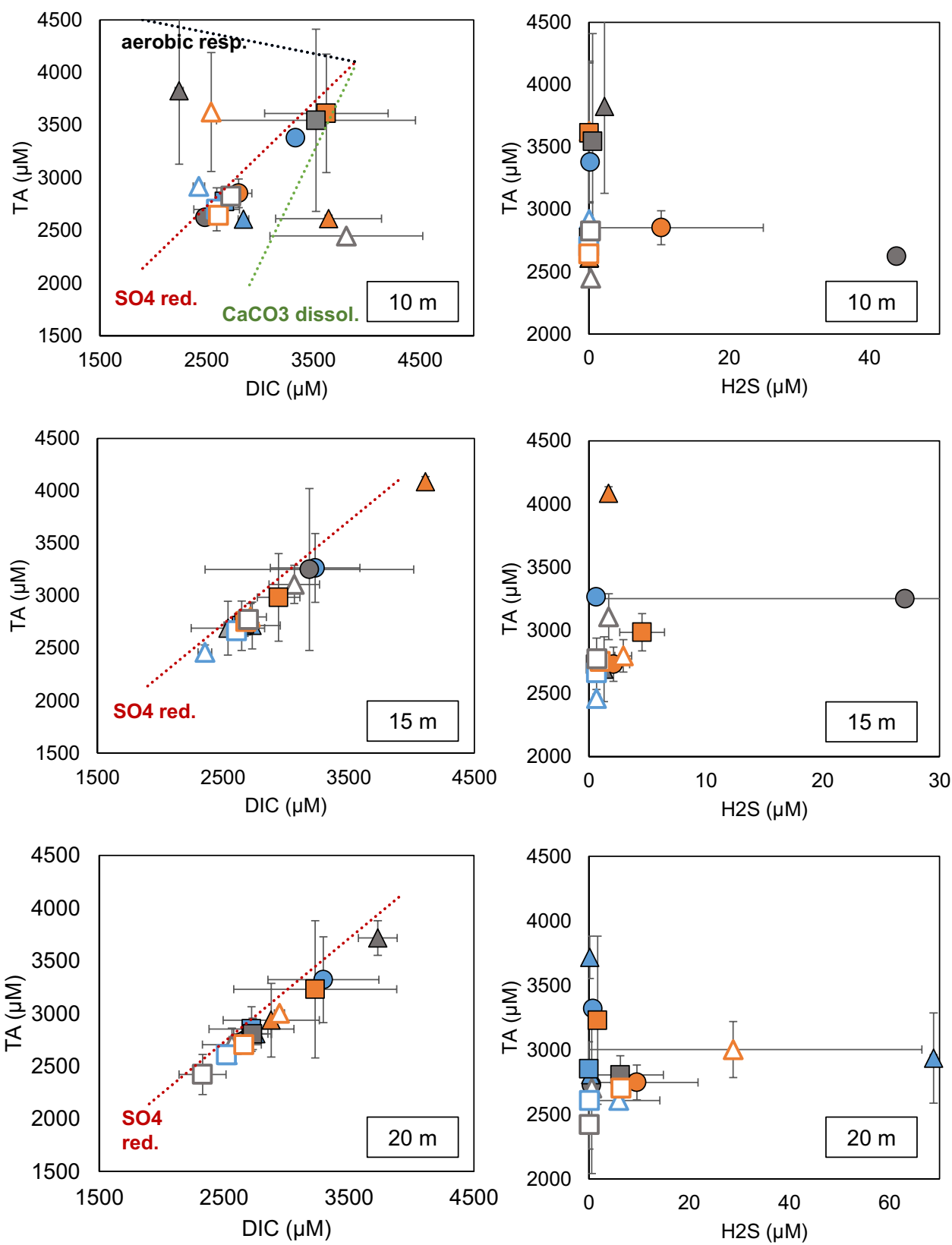

$\mathrm{NO}_{2}{ }^{-}+\mathrm{NO}_{3}{ }^{-}$concentrations were low (under $1 \mu \mathrm{M}$ ) at each station all along the year, except at the unvegetated colonized edge at $10 \mathrm{~m}$ depth in February and June (respectively, 8.52 and $8.80 \mu \mathrm{M})$. Ammonium $\left(\mathrm{NH}_{4}{ }^{+}\right)$showed a different pattern with the highest concentrations at $20 \mathrm{~m}$ depth in June at both vegetated and unvegetated colonized sides (respectively, 65.39 and $68.06 \mu \mathrm{M}$ ). This outline also occurred at $15 \mathrm{~m}$ depth in October for the same stations (Table 1). High $\mathrm{NH}_{4}{ }^{+}$concentrations were also found in February at all depths at the unvegetated eroded edge. $\mathrm{PO}_{4}{ }^{3-}$ concentrations were low (Table 1) with maximum values at $20 \mathrm{~m}$ at the vegetated colonized edge in February and June (respectively, 3.49 and $4.61 \mu \mathrm{M}$ ).

\section{Leaf biomass}

Leaf biomass reached its highest value $\left(1415 \mathrm{gDW} \mathrm{m}^{-2}\right)$ in June at $10 \mathrm{~m}$ at the colonized edge, and its lowest value (79 $\mathrm{gDW} \mathrm{m}^{-2}$ ) in February at the eroded edge (Fig. 6). At $10 \mathrm{~m}$ depth, significant differences were found between the colonized edge and both the continuous meadow and the eroded edge in June (Kruskal-Wallis: $p=0.0279$; KW-statistic $=18.67)$, and between colonized and eroded edge in October (Kruskal-Wallis: $p<0.0001 ; \mathrm{KW}$-statistic $=7.16$ ). At $15 \mathrm{~m}$ a single significant difference was observed between colonized and eroded edge in February (One-way ANOVA: $p=0.0013 ; F=7.52$ ). Finally, at $20 \mathrm{~m}$ depth, significant 
$10 \mathrm{~m}$
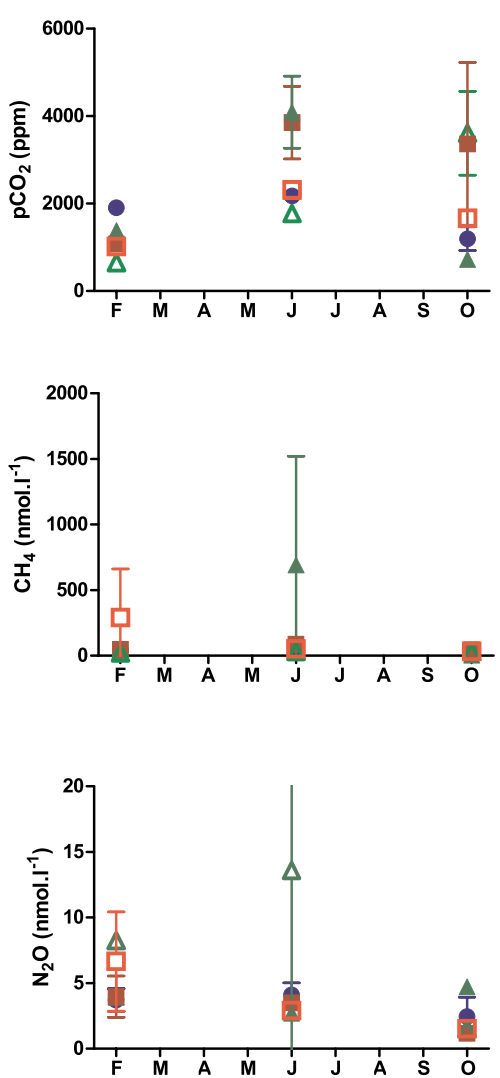

$15 \mathrm{~m}$
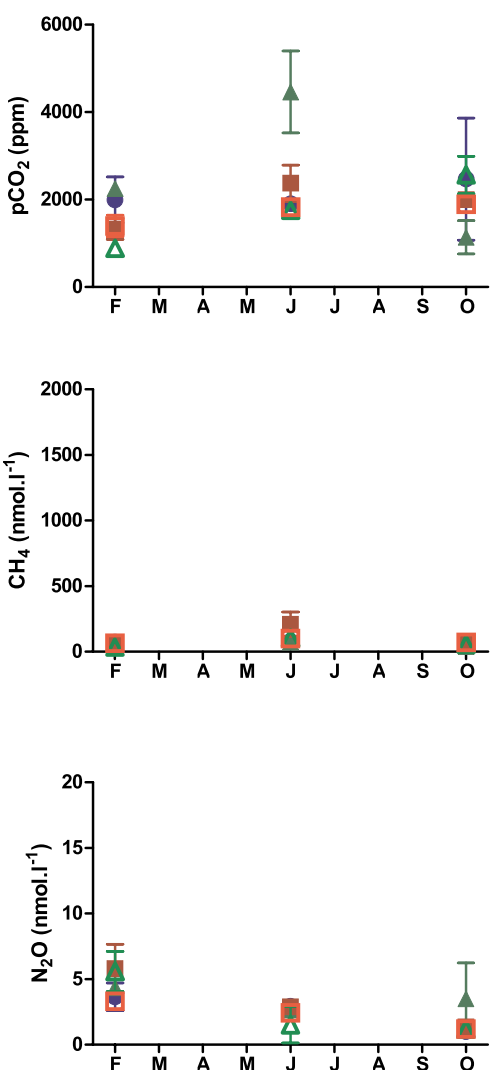

$20 \mathrm{~m}$
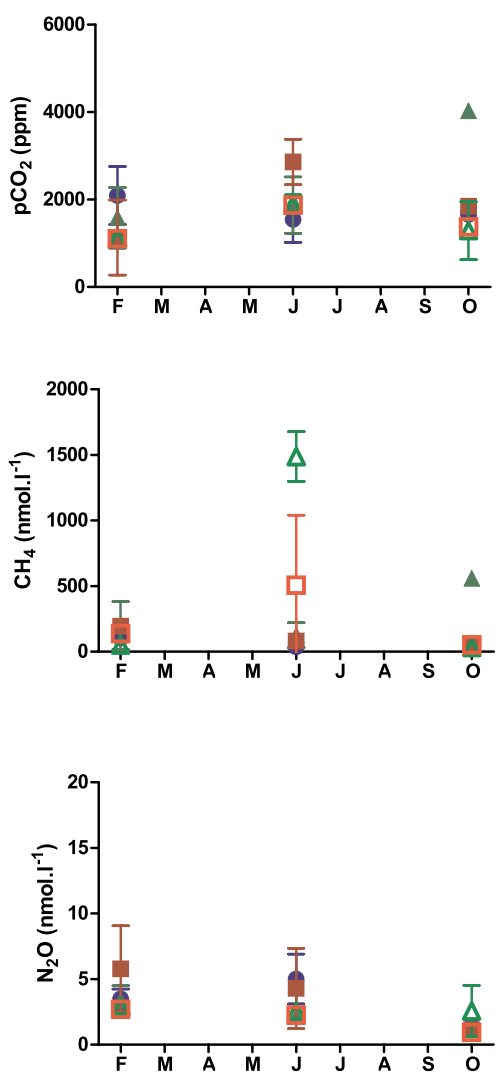

- Continuous meadow $\Delta$ Colonization vegetated $\Delta$ Colonization unvegetated

Erosion vegetated

Erosion unvegetated

Fig. 5 Mean values of $p \mathrm{CO}_{2}, \mathrm{CH}_{4}$ and $\mathrm{N}_{2} \mathrm{O}$ concentration at 10,15 and $20 \mathrm{~m}$ depth in sediment pore water. Vertical bars indicate $\mathrm{SD}$

differences were found between the eroded edge and both the continuous meadow and the colonized edge in February (one-way ANOVA: $p=0.0002 ; F=10.09$ ) and in June (Kruskal-Wallis: $p<0.0001 ; \mathrm{KW}$-statistic $=24.81$ ).

\section{Edge characteristics}

The percentage of variation expressed by the axis of the bi-dimensional representation for each PCA is around 95\% with a major contribution to the distribution of individuals of $p \mathrm{CO}_{2}$ at each depth ranging from 66 to $73 \%$ (Fig. 7). At 10 and $15 \mathrm{~m}$ depth, leaf biomass contributed up to $95 \%$ and at $20 \mathrm{~m} \mathrm{CH}_{4}$ contributed in the same range.

At all depths, no segregation pattern was found in February. At $10 \mathrm{~m}$ depth in June, the edge meadows (ColoM$\mathrm{J}$ and EroM-J) were separated from the unvegetated and continuous stations (Fig. 7). This pattern is also observed in October except for the continuous meadow (ContO) which is grouped with the vegetated colonized edge
(ColoM-O). A different arrangement was visible at $15 \mathrm{~m}$ depth with a single station segregated in June at the vegetated colonized edge (ColoM-J, Fig. 7). Finally, at $20 \mathrm{~m}$ depth the edge meadows (ColoM-J and EroM-J) were separated from the unvegetated and continuous stations in June, while in October the vegetated colonized edge (ColoM-O) alone was segregated (Fig. 7).

\section{Discussion}

By investigating the biogeochemical features of natural sandy patches within $P$. oceanica seascapes, our study highlights the seasonal and bathymetrical variability of their dynamics, as well as a contrast between the two edge types. These results allow us to provide some response elements to our four interrogations on patch chemistry dynamics. 
Table 1 Mean nutrient concentration (in $\mu \mathrm{M}$ ) \pm SD at each station in February, June and October 2015

\begin{tabular}{|c|c|c|c|c|c|c|c|c|c|}
\hline & \multicolumn{3}{|c|}{$\left[\mathrm{NO}_{2}^{-}\right]+\left[\mathrm{NO}_{3}^{-}\right]$} & \multicolumn{3}{|l|}{$\left[\mathrm{NH}_{4}^{+}\right]$} & \multicolumn{3}{|l|}{$\left[\mathrm{PO}_{4}{ }^{3-}\right]$} \\
\hline & February & June & October & February & June & October & February & June & October \\
\hline \multicolumn{10}{|l|}{$10 \mathrm{~m}$} \\
\hline Cont. meadow & $0.86 \pm 0.86$ & $0.64 \pm 0.62$ & $0.08 \pm 0.07$ & $1.63 \pm 0.63$ & $1.70 \pm 1.53$ & $2.64 \pm 3.04$ & $0.69 \pm 0.08$ & $0.57 \pm 0.39$ & $1.94 \pm 2.06$ \\
\hline $\begin{array}{l}\text { Colo. veg- } \\
\text { etated }\end{array}$ & $2.91 \pm 0.04$ & $0.90 \pm 0.21$ & $2.25 \pm 2.04$ & $1.85 \pm 0.49$ & $2.22 \pm 0.98$ & $1.33 \pm 0.62$ & $0.29 \pm 0.08$ & $0.94 \pm 0.06$ & $0.20 \pm 0.03$ \\
\hline $\begin{array}{l}\text { Colo. unveg- } \\
\text { etated }\end{array}$ & $8.52 \pm 0.62$ & $8.80 \pm 0.42$ & $0.19 \pm 0.04$ & $0.32 \pm 0.1$ & $0.79 \pm 0.35$ & $1.61 \pm 0.11$ & $0.15 \pm 0.01$ & $0.36 \pm 0.05$ & $0.45 \pm 0.13$ \\
\hline Ero. vegetated & $0.98 \pm 0.46$ & $0.67 \pm 0.06$ & $0.25 \pm 0.12$ & $1.21 \pm 0.95$ & $4.45 \pm 0.46$ & $1.38 \pm 1.17$ & $0.46 \pm 0.06$ & $0.78 \pm 0.37$ & $0.27 \pm 0.14$ \\
\hline $\begin{array}{l}\text { Ero. unveg- } \\
\text { etated }\end{array}$ & $0.44 \pm 0.15$ & $0.09 \pm 0.01$ & $0.36 \pm 0.26$ & $20.78 \pm 9.4$ & $1.39 \pm 0.78$ & $4.74 \pm 2.77$ & $0.22 \pm 0.04$ & $0.26 \pm 0.02$ & $0.31 \pm 0.04$ \\
\hline \multicolumn{10}{|l|}{$15 \mathrm{~m}$} \\
\hline Cont. meadow & $0.17 \pm 0.08$ & $0.30 \pm 0.04$ & $0.36 \pm 0.06$ & $0.72 \pm 0.28$ & $8.61 \pm 7.67$ & $8.91 \pm 9.58$ & $0.8 \pm 0.04$ & $0.74 \pm 0.52$ & $1.23 \pm 0.76$ \\
\hline $\begin{array}{l}\text { Colo. veg- } \\
\text { etated }\end{array}$ & $0.35 \pm 0.32$ & $0.19 \pm 0.17$ & $0.10 \pm 0.02$ & $20.04 \pm 20.62$ & $2.45 \pm 1.29$ & $10.62 \pm 0.34$ & $0.95 \pm 0.13$ & $1.52 \pm 1.48$ & $0.67 \pm 0.19$ \\
\hline $\begin{array}{l}\text { Colo. unveg- } \\
\text { etated }\end{array}$ & $0.91 \pm 1.12$ & $0.40 \pm 0.13$ & $0.49 \pm 0.66$ & $1.94 \pm 1.8$ & $1.78 \pm 1.06$ & $10.06 \pm 4.59$ & $0.62 \pm 0.55$ & $0.56 \pm 0.18$ & $1.89 \pm 0.99$ \\
\hline Ero. vegetated & $1.27 \pm 0.02$ & $0.36 \pm 0.26$ & $0.78 \pm 0.49$ & $1.03 \pm 0.4$ & $9.13 \pm 7.98$ & $2.19 \pm 2.59$ & $0.45 \pm 0.08$ & $0.86 \pm 0.62$ & $0.27 \pm 0.21$ \\
\hline $\begin{array}{l}\text { Ero. unveg- } \\
\text { etated }\end{array}$ & $0.66 \pm 0.68$ & $0.34 \pm 0.33$ & $0.18 \pm 0.06$ & $7.64 \pm 0.98$ & $7.35 \pm 0.81$ & $14.19 \pm 0.44$ & $1.10 \pm 0.84$ & $0.73 \pm 0.18$ & $0.65 \pm 0.1$ \\
\hline \multicolumn{10}{|l|}{$20 \mathrm{~m}$} \\
\hline Cont. meadow & $1.22 \pm 1.12$ & $0.58 \pm 0.61$ & $0.47 \pm 0.21$ & $3.25 \pm 0.5$ & $10.28 \pm 6.26$ & $16.74 \pm 7.61$ & $0.61 \pm 0.22$ & $1.59 \pm 0.11$ & $2.09 \pm 0.49$ \\
\hline $\begin{array}{l}\text { Colo. veg- } \\
\text { etated }\end{array}$ & $0.32 \pm 0.2$ & $0.13 \pm 0.11$ & $0.27 \pm 0.21$ & $10.7 \pm 8.57$ & $65.39 \pm 21.71$ & $11.76 \pm 9.07$ & $3.49 \pm 1.17$ & $4.61 \pm 1.22$ & $1.54 \pm 0.63$ \\
\hline $\begin{array}{l}\text { Colo. unveg- } \\
\text { etated }\end{array}$ & $0.62 \pm 0.48$ & $0.19 \pm 0.07$ & $0.24 \pm 0.17$ & $9.20 \pm 12.26$ & $68.06 \pm 44.28$ & $5.17 \pm 5.81$ & $1.31 \pm 1.65$ & $3.02 \pm 2.44$ & $1.39 \pm 0.71$ \\
\hline Ero. vegetated & $0.21 \pm 0.06$ & $0.41 \pm 0.08$ & $0.25 \pm 0.06$ & $6.77 \pm 1.99$ & $21.91 \pm 6.95$ & $5.38 \pm 1.51$ & $1.53 \pm 0.01$ & $2.22 \pm 0.63$ & $0.94 \pm 0.07$ \\
\hline $\begin{array}{l}\text { Ero. unveg- } \\
\text { etated }\end{array}$ & $0.13 \pm 0.01$ & $0.08 \pm 0.05$ & $0.29 \pm 0.23$ & $15.45 \pm 4.3$ & $7.01 \pm 1.48$ & $4.29 \pm 2.49$ & $1.56 \pm 0.26$ & $1.58 \pm 0.04$ & $0.97 \pm 0.3$ \\
\hline
\end{tabular}

Cont. continuous, Colo. colonized edge, Ero eroded edge

\section{P. oceanica matrix versus patch edges}

Our results show that sediment characteristics of continuous $P$. oceanica meadows adjacent to natural sandy patches, i.e. the matrix, differed from those of unvegetated sediments of sand corridors (Fig. 7). This phenomenon was previously assessed in $P$. oceanica meadows at $7 \mathrm{~m}$ depth in Magaluf Bay by Barrón et al. (2006), where a higher production and dissolution of $\mathrm{CaCO}_{3}$ within vegetated sediments was assessed. In the present work, this report depends on the type of edge considered, with eroded unvegetated edges showing less contrast with the continuous meadow than colonized ones. In this way, at a comparable depth $(10 \mathrm{~m})$, TA was found to have seasonally higher values within the continuous meadow than within unvegetated colonized sediments, revealing an enhanced $\mathrm{CaCO}_{3}$ dissolution that is possibly sustained by an equally higher $\mathrm{CaCO}_{3}$ production from calcification by epibionts and dwelling invertebrates (Fig. 4). This contrast was not observed at the eroded unvegetated edge which showed a pattern similar to the continuous meadow. A stronger contrast between the matrix and the two unvegetated edges is observed when looking at the nutrient results with higher concentrations of $\mathrm{NH}_{4}{ }^{+}$within unvegetated sediments than in continuous meadow (Table 1). These higher concentrations in inorganic nutrients suggest that the degradation of litter (Mateo and Romero 1997; Gacia et al. 2002) and collapsed meadow overhangs from the vertical edge (Pedersen et al. 2011) may be incorporated within sediments through the process of ammonification (López et al. 1998; Romero et al. 2006). This recycled nutrient pool may provide suitable conditions for the development and beginning of the colonization process of $P$. oceanica; however, since we do not have any data on litter accumulation and its nutrient release, this phenomenon remains hypothetical. Indeed, the high uptake and recycling capacity of the plant concerning nutrients (Gacia et al. 2002; Lepoint et al. 2002) may explain the higher nutrient values observed on the unvegetated sand.

The $P$. oceanica matrix also showed heterogeneous biogeochemical differences with the two different vegetated patch edges. The vegetated colonized edge showed 

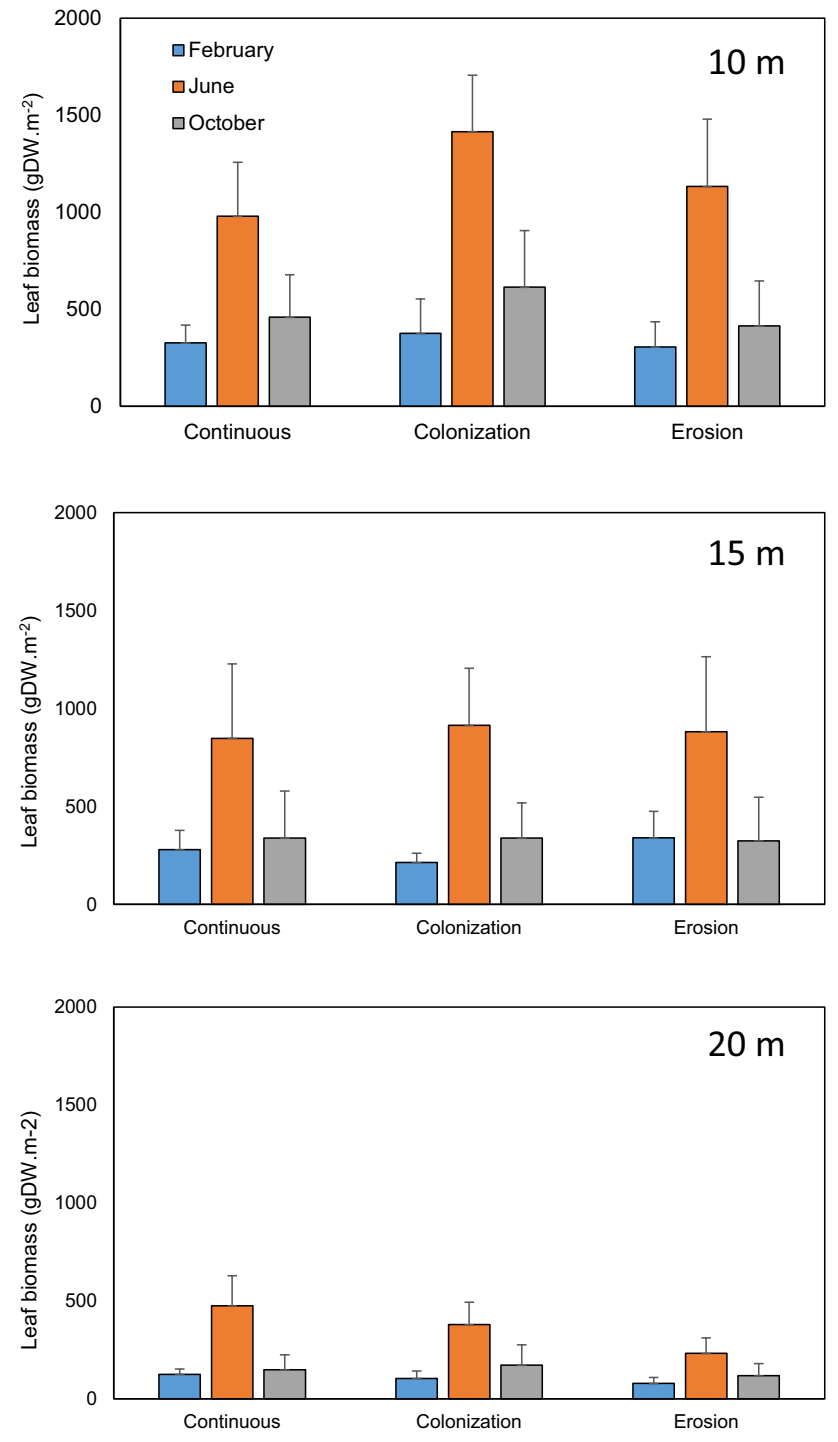

Fig. 6 Leaf biomass at 10, 15 and $20 \mathrm{~m}$ depth in the continuous meadow, the colonized border and the eroded edge in February (blue), June (orange) and October (grey)

contrasted biogeochemical characteristics with regard to the eroded one (Fig. 7). Like mentioned above for unvegetated edges, this difference was mainly highlighted by the distribution of inorganic nutrients. We speculate that through an increase of the dead leaf trapping and other organic debris, the canopy at the colonized edge may allow nutrient recycling (de Boer 2007) and thus the colonization of the sand corridor. This dual assessment is supported by the leaf biomass which is always equal or higher at the colonized edge than at the eroded edge (Fig. 6). This pattern, linked with a similar or higher DIC (Fig. 4) and $p \mathrm{CO}_{2}$ (Fig. 5), suggests better conditions within the sediments for the colonization process (Invers et al. 1997). Conversely, by colonizing bare substrates, $P$. oceanica also modifies the biogeochemical characteristics of the sediments (Marbà et al. 2006).

\section{Influence of seasonality}

Although several general disparities between eroded and colonized edge are outlined, the biogeochemical dynamics within temperate seagrass sediments must be seasonally investigated (Marba et al. 1996; Barrón et al. 2006). The results of the present work, in agreement with Canals and Ballesteros (1997) and Barrón et al. (2006), suggest that in February $\mathrm{CaCO}_{3}$ dissolution was mainly responsible for increase of TA (Fig. 4) through the decrease of temperature (Fig. 3), which reduces $\mathrm{CaCO}_{3}$ saturation and enhances its dissolution. In June, the increase of TA (Fig. 4) was mainly driven by sulphate reduction (Holmer et al. 2003, 2004). Added to this abiotic process, other biotic phenomena should influence $\mathrm{CaCO}_{3}$ within the sediments, such as the precipitation of carbonate skeletons was favoured in summer by high temperatures (Mutti and Hallock 2003), which greatly increased the $\mathrm{CaCO}_{3}$ sediment content (Serrano et al. 2012). This biogenic carbonate stems from $P$. oceanica leaf and rhizome calcified epiphytes (Mazarrasa et al. 2015).

Moreover, we hypothesize that the general high availability of nutrients within the vegetated sediments in June is linked with the inability of $P$. oceanica to uptake nutrients in summer, its optimal period for development being the winter/autumn period (Enriquez et al. 2004). This is consistent with our data of October and February, which generally show lower nutrient availability in vegetated sediments (Table 1).

From February to October, a general trend in the diminution of $\mathrm{N}_{2} \mathrm{O}$ was observed at all stations, reflecting an increase of denitrification from the inorganic nutrient pool through the year (Fig. 5). This process is classically found to be higher in seagrass meadows than in unvegetated sediments (Caffrey and Kemp 1990; Romero et al. 2006; Eyre et al. 2011).

When analysing seasonally several variables of the sediment chemistry, it appears that the main contrasts between continuous meadow, and vegetated eroded and colonized edges were greater in June, especially for the colonized stations (Fig. 7). Our results thus highlight the potential of the summer period for sampling and assessment of chemical processes within a seagrass under colonization processes (Fig. 8). This statement is particularly observed for $\mathrm{H}_{2} \mathrm{~S}$ measurements (Fig. 4) with higher concentrations recorded during the seasonal warm period (Calleja et al. 2007; García-Martínez et al. 2009; García et al. 2012). 
Fig. 7 Biplot of the PCA analysis at 10, 15 and $20 \mathrm{~m}$ for each station in February ( $\mathrm{F}$, blue $)$, June (J, orange) and October $(\mathrm{O}$, grey). The percentage reflects the proportion of variance expressed by each axe. Cont continuous meadow, ColoM colonization meadow, ColoB colonization bare sediment, EroM erosion meadow, $E r o B$ erosion bare sediment. Red lines represent variables contributions. Only variables with high percentage of contribution are labelled

\section{Bathymetrical display of chemical characteristics}

In parallel with seasonal variations, strong bathymetrical disparities were also observed when looking at the duality between eroded and colonized vegetated edges. Higher differences were found at the lowest depth of this study $(10 \mathrm{~m})$ and decrease while the depth increases (Fig. 8). These disparate features were mainly driven by the leaf biomass and the carbonate system properties. A depth gradient was clearly observable concerning the leaf biomass (Bay 1984; Buia et al. 1992) which was the highest at $10 \mathrm{~m}$ depth at the colonized edge, shows less variations between the continuous meadow and the two edges at $15 \mathrm{~m}$, and finally is higher within the continuous adjacent meadow than in the colonized and eroded edges at $20 \mathrm{~m}$ (Fig. 6). These results are not consistent with pore water nutrient concentrations measured in this study that increased with depth (Fig. 8). It is thus more probable that this difference in leaf biomass is ascribable to the diminution of light intensity and the photosynthetic activity of the plant at increasing depths (Olesen et al. 2002), although this decrease of illuminance was observed only between 10 and 15/20 m depth and not between 15 and $20 \mathrm{~m}$.

Although these distinct physico-chemical and biotic particularities offer a better understanding of the processes occurring at the edges of sand patches within seagrass meadows, these data do not allow us to conclude about the influence of sediment biogeochemical characteristics over the different shapes of natural sand patches observed along a bathymetric gradient by Abadie et al. (2015).

\section{Conclusion}

Natural sand patches within P. oceanica seascapes show contrasted biogeochemical features at different spatial and temporal scales. We are now able to answer the four questions asked at the beginning of this paper:

1. Chemical and biotic features within the P. oceanica matrix are generally separated from those of the sand patch edges, particularly with the colonized one.

2. The two types of edges (eroded vertical edge versus colonized edge) are distinct from one another from a biogeochemical viewpoint.
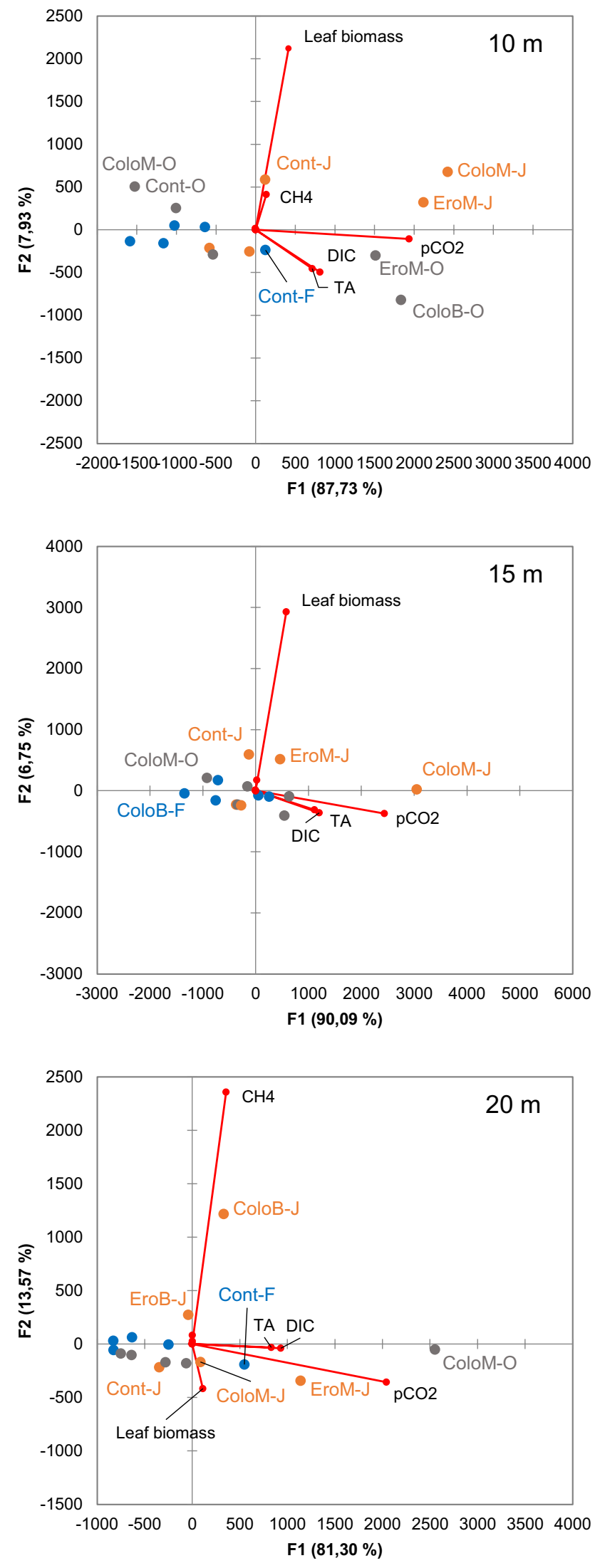


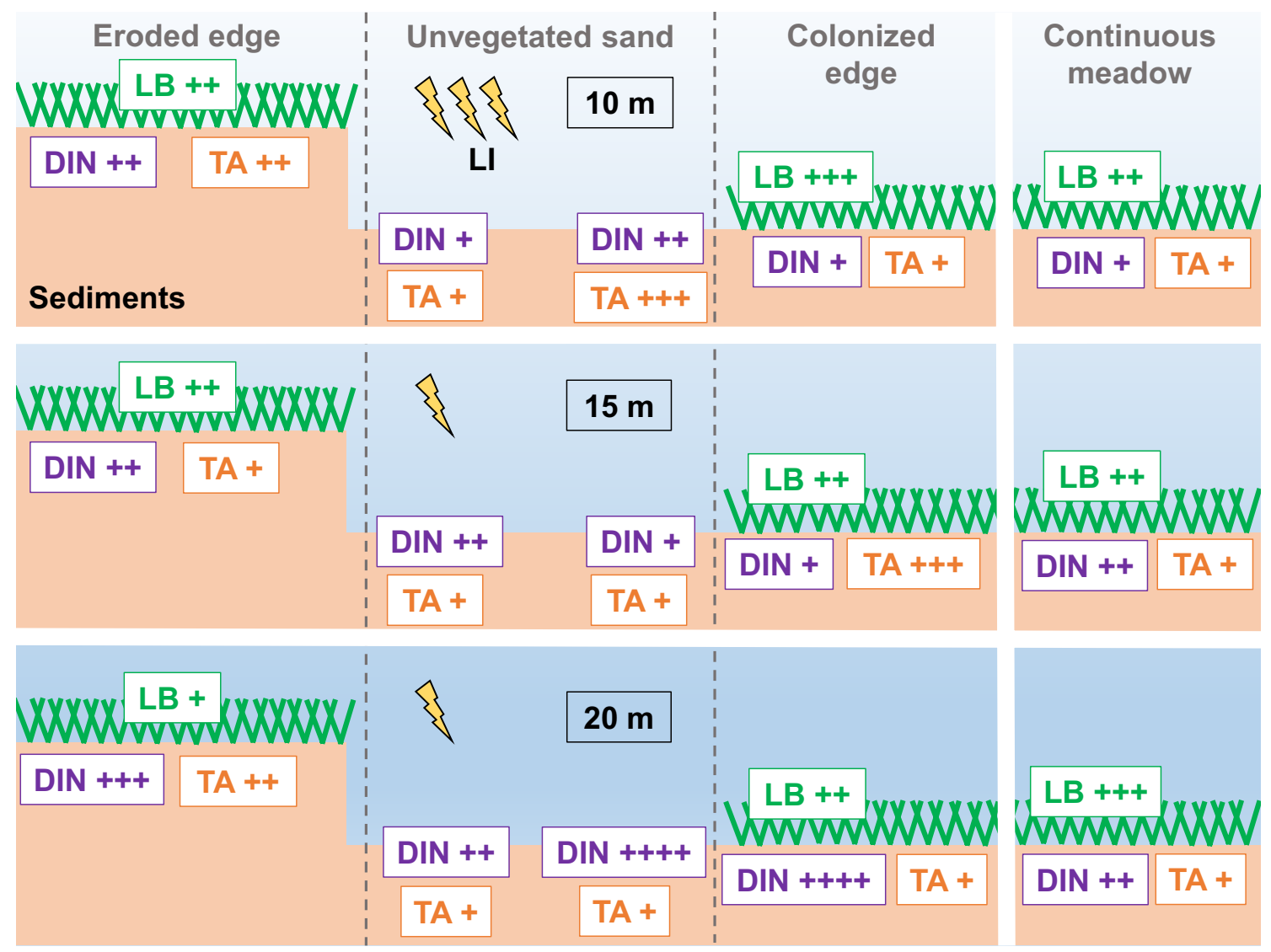

Fig. 8 Summary of leaf biomass (LB, green), dissolved inorganic nitrogen (DIN, purple) and total alkalinity (TA, orange) in June at 10, 15 and $20 \mathrm{~m}$ depth for each compartment investigated. $L I$ light intensity

3. Seasonality plays an important role through temperature variations and their influence on the sulphate reduction in sediments, as well as the $\mathrm{CaCO}_{3}$ dissolution and its production by biological processes.

4. A depth gradient is observed at the level of the leaf biomass ascribable in part to the decrease of light intensity (Olesen et al. 2002) and the presence of a thermocline during the warm period.

This study supports the importance of the capacity of seagrasses to modify the biogeochemical characteristics of the sediments, especially during the colonization process. We hypothesize that such particularities play an important role in the natural sand patch dynamics of $P$. oceanica seascapes. Moreover, although the study of biogeochemical processes provides invaluable data to understand the natural colonization of bare sediments by seagrasses, it can also lead to a new understanding of anthropogenic impacts (e.g. anchoring, aquaculture, pollution) leading to meadow erosion.
Acknowledgements We thank Marc-Vincent Commarieu for TA analysis, and Renzo Biondo for nutrient analysis. We also thank Jonathan Richir, Nicolas Cimiterra and Michèle Leduc for their support during the scuba diving sampling and the acquisition of the temperature and light data. This study is part of the STARE-CAPMED (STAtion of Reference and rEsearch on Change of local and global Anthropogenic Pressures on Mediterranean Ecosystems Drifts) program funded by the Territorial Collectivity of Corsica and by the French Water Agency (PACA-Corsica). The GC was acquired with funds from the Fonds National de la Recherche Scientifique (FNRS) (Contract No. 2.4.598.07). Alberto V. Borges is a senior research associate at the FNRS. Arnaud Abadie acknowledges a CIFRE Ph.D. Grant (2013/0470) of the French ANRT (Association Nationale Recherche Technologie). We thank the two anonymous referees who contributed to improve the manuscript with constructive comments.

\section{Compliance with ethical standards}

Conflict of interest The authors declare that they have no conflict of interest.

Ethical approval This article does not contain any studies with animals performed by any of the authors. 


\section{References}

Abadie A, Gobert S, Bonacorsi M, Lejeune P, Pergent G, PergentMartini C (2015) Marine space ecology and seagrasses. Does patch type matter in Posidonia oceanica seascapes? Ecol Indic 57:435-446. doi:10.1016/j.ecolind.2015.05.020

Abadie A, Lejeune P, Pergent G, Gobert S (2016) From mechanical to chemical impact of anchoring in seagrasses: the premises of anthropogenic patch generation in Posidonia oceanica meadows. Mar Pollut Bull 109:61-71

Aminot A, Kérouel R (2007) Dosage automatique des nutriments dans les eaux marines. Editions Quae Ifremer, Versailles

Angelstam P (1992) Conservation of communities-the importance of edges, surroundings and landscape mosaic structure ecological principles of nature conservation. Springer, Berlin, pp 9-70

Barrón C, Duarte CM, Frankignoulle M, Borges AV (2006) Organic carbon metabolism and carbonate dynamics in a Mediterranean seagrass (Posidonia oceanica) meadow. Estuar Coast 29:417-426. doi:10.1007/BF02784990

Bay D (1984) A field study of he growth dynamics and productivity of Posidonia oceanica (L.) Delile in Calvi Bay, Corsica. Aquat Bot 20:43-64

Beck MW, Heck KL, Able KW, Childers DL, Eggleston DB, Gillanders BM, Halpern BS, Hays CG, Hoshino K, Minello TJ, Orth RJ, Sheridan PF, Weinstein MP (2001) The identification, conservation, and management of estuarine and marine nurseries for fish and invertebrates. Bioscience 51:633-641. doi:10.1641/0006-3568(2001)051[0633:TICAMO]2.0.CO;2

Borg JA, Rowden AA, Attrill MJ, Schembri PJ, Jones MB (2006) Wanted dead or alive: high diversity of macroinvertebrates associated with living and 'dead' Posidonia oceanica matte. Mar Biol 149(3):667-677. doi:10.1007/s00227-006-0250-3

Borges AV, Darchambeau F, Teodoru CR, Marwick TR, Tamooh F, Geeraert N, Omengo FO, Guerin F, Lambert T, Morana C, Okuku E, Bouillon S (2015) Globally significant greenhouse-gas emissions from African inland waters. Nat Geosci 8:637-642. doi:10.1038/ngeo2486. http://www.nature.com/ngeo/journal/v8/ n8/abs/ngeo2486.html-supplementary-information

Boström C, Jackson EL, Simenstad CA (2006) Seagrass landscapes and their effects on associated fauna: a review. Estuar Coast Shelf Sci 68:383-403. doi:10.1016/j.ecss.2006.01.026

Brooks KM (2001) An evaluation of the relationship between salmon farm biomass, organic inputs to sediments, physicochemical changes associated with those inputs and the infaunal response-with emphasis on total sediment sulfides, total volatile solids, and oxidation-reduction potential as surrogate endpoints for biological monitoring. Aquatic Environmental Sciences, 644 Old Eaglemount Road, Port Townsend, Washington 98368

Buia MC, Zupo V, Mazzella L (1992) Primary production and growth dynamics in Posidonia oceanica. Mar Ecol 13:2-16

Burdige DJ, Zimmerman RC (2002) Impact of sea grass density on carbonate dissolution in Bahamian sediments. Limnol Oceanogr 47:1751-1763

Caffrey JM, Kemp WM (1990) Nitrogen cycling in sediments with estuarine populations of Potamogeton perfoliatus and Zostera marina. Mar Ecol Prog Ser 66:147-160

Calleja ML, Marbà N, Duarte CM (2007) The relationship between seagrass (Posidonia oceanica) decline and sulfide porewater concentration in carbonate sediments. Estuar Coast Shelf Sci 73:583-588. doi:10.1016/j.ecss.2007.02.016

Canals M, Ballesteros E (1997) Production of carbonate particles by phytobenthic communities on the Mallorca-Menorca shelf, northwestern Mediterranean Sea. Deep Sea Res II (Top Stud Oceanogr) 44:611-629
Carpenter JH (1965) The accuracy of the Winkler method for dissolved oxygen analysis. Limnol Oceanogr 10:135-140. doi:10.4319/ 10.1965.10.1.0135

Clabaut P, Augris C, Pergent G, Pergent-Martini C, Pasqualini V, Bonacorsi M (2014) Les fonds marins côtiers de Corse. Cartographie biomorphosédimentaire. Editions Quae, Versailles

Dauby P, Poulicek M (1995) Methods for removing epiphytes from seagrasses: SEM observations on treated leaves. Aquat Bot $52: 217-228$

de Boer WF (2007) Seagrass-sediment interactions, positive feedbacks and critical thresholds for occurrence: a review. Hydrobiologia 591:5-24

de los Santos CB, Vicencio-Rammsy B, Lepoint G, Remy F, Bouma TJ, Gobert S (2016) Ontogenic variation and effect of collection procedure on leaf biomechanical properties of Mediterranean seagrass Posidonia oceanica (L.) Delile. Mar Ecol 37(4):750 759. doi: $10.1111 / \mathrm{maec} .12340$

den Hartog C (1970) The sea-grasses of the world. North-Holland Pub. Co., Amsterdam

Díaz-Almela E, Marbà N, Martínez R, Santiago R, Duarte CM (2009) Seasonal dynamics of Posidonia oceanica in Magaluf Bay (Mallorca, Spain): temperature effects on seagrass mortality. Limnol Oceanogr 54:2170-2182. doi:10.4319/ 10.2009.54.6.2170

Dickson AG (1993) pH buffers for sea water media based on the total hydrogen ion concentration scale. Deep Sea Res Part I 40:107-118

Dickson AG, Millero FJ (1987) A comparison of the equilibrium constants for the dissociation of carbonic acid in seawater media. Deep Sea Res A Oceanogr Res Pap 34:1733-1743

Elkalay K, Frangoulis C, Skliris N, Goffart A, Gobert S, Lepoint G, Hecq J-H (2003) A model of the seasonal dynamics of biomass and production of the seagrass Posidonia oceanica in the Bay of Calvi (Northwestern Mediterranean). Ecol Model 167:1-18. doi:10.1016/S0304-3800(03)00074-7

Enriquez S, Marbà N, Cebriàn J, Duarte CM (2004) Annual variation in leaf photosynthesis and leaf nutrient content of four Mediterranean seagrasses. Bot Mar 47:295-306

Eyre BD, Ferguson AJP, Webb A, Maher D, Oakes JM (2011) Denitrification, $\mathrm{N}$-fixation and nitrogen and phosphorus fluxes in different benthic habitats and their contribution to the nitrogen and phosphorus budgets of a shallow oligotrophic sub-tropical coastal system (southern Moreton Bay, Australia). Biogeochemistry 102:111-133. doi:10.1007/s10533-010-9425-6

Forman RTT (1995) Land mosaics: the ecology of landscapes and regions. Cambridge University Press, Cambridge

Fourqurean JW, Duarte CM, Kennedy H, Marba N, Holmer M, Mateo MA, Apostolaki ET, Kendrick GA, Krause-Jensen D, McGlathery KJ, Serrano O (2012) Seagrass ecosystems as a globally significant carbon stock. Nat Geosci 5:505-509. http://www.nature.com/ngeo/journal/v5/n7/abs/ngeo 1477 . html-supplementary-information

Gacia E, Duarte C, Middelburg JJ (2002) Carbon and nutrient deposition in a Mediterranean seagrass (Posidonia oceanica) meadow. Limnol Oceanogr 47:23-32

García R, Sánchez-Camacho M, Duarte CM, Marbà N (2012) Warming enhances sulphide stress of Mediterranean seagrass (Posidonia oceanica). Estuar Coast Shelf Sci 113:240-247. doi:10.1016/j. ecss.2012.08.010

García-Martínez M, López-López A, Calleja ML, Marbà N, Duarte CM (2009) Bacterial community dynamics in a seagrass (Posidonia oceanica) meadow sediment. Estuar Coast 32:276-286

Gera A, Pages JF, Romero J, Alcoverro T (2013) Combined effects of fragmentation and herbivory on Posidonia oceanica seagrass ecosystems. J Ecol 101:1053-1061 
Giraud G (1979) Sur une méthode de mesure et de comptage des structures foliaires de Posidonia oceanica (Linnaeus) Delile. Bull Mus d'Histoire Nat Marseille 39:33-39

Gobert S, Lepoint G, Biondo R, Bouquegneau JM (2006) In situ sampling of pore waters from seagrass meadows. Biol Mar Mediterr 13:230-234

Gobert S, Lepoint G, Pelaprat C, Remy F, Lejeune P, Richir J, Abadie A (2016) Temporal evolution of sand corridors in a Posidonia oceanica seascape: a 15-years study. Mediterr Mar Sci 17:777784. doi: $10.12681 / \mathrm{mms} .1816$

Gran G (1952) Determination of the equivalence point in potentiometric titrations of seawater with hydrochloric acid. Oceanol Acta 5:209-218

Holmer M, Frederiksen MS (2007) Stimulation of sulfate reduction rates in Mediterranean fish farm sediments inhabited by the seagrass Posidonia oceanica. Biogeochemistry (Dordrecht) 85:169-184

Holmer M, Duarte CM, Marbá N (2003) Sulfur cycling and seagrass (Posidonia oceanica) status in carbonate sediments. Biogeochemistry 66:223-239

Holmer M, Duarte CM, Boschker HTS, Barrón C (2004) Carbon cycling and bacterial carbon sources in pristine and impacted Mediterranean seagrass sediments. Aquat Microb Ecol 36(3):227237. doi: $10.3354 / a m e 036227$

Infantes E, Terrados J, Orfila A, Cañellas B, Álvarez-Ellacuria A (2009) Wave energy and the upper depth limit distribution of Posidonia oceanica. Bot Mar 52:419-427. doi:10.1515/ BOT.2009.050

Invers O, Romero J, Pérez M (1997) Effects of pH on seagrass photosynthesis: a laboratory and field assessment. Aquat Bot 59:185-194

Ku TCW, Walter LM, Coleman ML, Blake RE, Martini AM (1999) Coupling between sulfur recycling and syndepositional carbonate dissolution: evidence from oxygen and sulfur isotope composition of pore water sulfate, South Florida Platform, USA. Geochim Cosmochim Acta 63:2529-2546

Lawton JH (1994) What do species do in ecosystems? Oikos 71:367374. doi: $10.2307 / 3545824$

Lepoint G, Millet S, Dauby P, Gobert S, Bouquegneau JM (2002) Annual nitrogen budget of the seagrass Posidonia oceanica as determined by in situ uptake experiments. Mar Ecol Prog Ser 237:87-96

Lewis E, Wallace DWR (1998) CO2SYS-program developed for the $\mathrm{CO}_{2}$ system calculations. Carbon Dioxide Information Analysis Center, Oak Ridge

Li X, Mander U (2009) Future options in landscape ecology: development and research. Prog Phys Geol 33:31-48. doi:10.1177/0309133309103888

López NI, Duarte CM, Vallespinós F, Romero J, Alcoverro T (1998) The effect of nutrient additions on bacterial activity in seagrass (Posidonia oceanica) sediments. J Exp Mar Biol Ecol 224:155166. doi:10.1016/S0022-0981(97)00189-5

Marba N, Cebrian J, Enriquez S, Duarte CM (1996) Growth patterns of Western Mediterranean seagrasses: species-specific responses to seasonal forcing. Mar Ecol Prog Ser 133:203-215

Marbà N, Holmer M, Gacia E, Barron C (2006) Seagrass beds and coastal biogeochemistry. In: Larkum AWD, Orth RJ, Duarte CM (eds) Seagrasses: biology, ecology and conservation. Springer, Berlin, pp 135-157
Mateo MA, Romero J (1997) Detritus dynamics in the seagrass Posidonia oceanica: elements for an ecosystem carbon and nutrient budget. Mar Ecol Prog Ser 151:43-53

Mazarrasa I, Marbà N, Lovelock CE, Serrano O, Lavery PS, Fourqurean JW, Kennedy H, Mateo MA, Krause-Jensen D, Steven ADL (2015) Seagrass meadows as a globally significant carbonate reservoir. Biogeosci Disc 12(16):4993-5003. doi:10.5194/ bg-12-4993-2015

Mehrbach C, Culberson CH, Hawley JE, Pytkowicx RM (1973) Measurement of the apparent dissociation constants of carbonic acid in seawater at atmospheric pressure. Limnol Oceanogr 18:897-907. doi:10.4319/lo.1973.18.6.0897

Molinier R, Picard J (1952) Recherches sur les herbiers de phanérogames marines du littoral méditerranéen français. Ann Inst Oceanogr 27:157-234

Mutti M, Hallock P (2003) Carbonate systems along nutrient and temperature gradients: some sedimentological and geochemical constraints. Int J Earth Sci 92:465-475

Olesen B, Enríquez S, Duarte CM, Sand-Jensen K (2002) Depthacclimation of photosynthesis, morphology and demography of Posidonia oceanica and Cymodocea nodosa in the Spanish Mediterranean Sea. Mar Ecol Prog Ser 236:89-97

Ondiviela B, Losada IJ, Lara JL, Maza M, Galván C, Bouma TJ, van Belzen J (2014) The role of seagrasses in coastal protection in a changing climate. Coast Eng 87:158-168. doi:10.1016/j. coastaleng.2013.11.005

Pedersen MO, Serrano O, Mateo MA, Holmer M (2011) Temperature effects on decomposition of a Posidonia oceanica mat. Aquat Microb Ecol 65:169-182. doi:10.3354/ame01543

Prado P, Alcoverro T, Romero J (2009) Welcome mats? The role of seagrass meadow structure in controlling post-settlement survival in a keystone sea-urchin species. Estuar Coast Shelf Sci 85:472-478

Robbins BD, Bell SS (1994) Seagrass landscapes: a terrestrial approach to the marine subtidal environment. Trends Ecol Evol 9:301-304. doi:10.1016/0169-5347(94)90041-8

Romero J, Lee K-S, Pérez M, Mateo MA, Alcoverro T (2006) Nutrient dynamics in seagrass ecosystems. In: Larkum AWD, Orth RJ, Duarte CM (eds) Seagrasses: biology, ecology and conservation. Springer, Berlin, pp 227-254

Serrano O, Mateo MA, Renom P, Julià R (2012) Characterization of soils beneath a Posidonia oceanica meadow. Geoderma 185 186:26-36. doi:10.1016/j.geoderma.2012.03.020

Strickland JDH, Parsons TR (1972) A practical handbook of seawater analysis. Fisheries Research Board of Canada

Turner MG (1989) Landscape ecology: the effect of pattern on process. Annu Rev Ecol Evol Syst 20:171-197

Vacchi M, Montefalcone M, Bianchi CN, Morri C, Ferrari M (2012) Hydrodynamic constraints to the seaward development of Posidonia oceanica meadows. Estuar Coast Shelf Sci 97:58-65. doi:10.1016/j.ecss.2011.11.024

Vacchi M, De Falco G, Simeone S, Montefalcone M, Morri C, Ferrari M, Bianchi CN (2017) Biogeomorphology of the Mediterranean Posidonia oceanica seagrass meadows. Earth Surf Proc Land 42:42-54. doi:10.1002/esp.3932

Weiss RF (1981) Determinations of carbon dioxide and methane by dual catalyst flame ionization chromatography and nitrous oxide by electron capture chromatography. J Chromatogr Sci 19:611-616 